\title{
REVISITING THE PARADOX OF ÀBÍKÚ (BO RN-TO-DIE) IN THE THROES OF MODERN HEALTHCARE DELIVERY SYSTEM AMONG YORUBA PEOPLE
}

\author{
Ogunleye Adetunbi Richard (PhD) \\ Department of Religion and African Culture \\ Adekunle Ajasin University, Akungba-Akoko \\ Ondo State, Nigeria. \\ E-mail: oguntunbi@gmail.com \\ Phone no: +2348166782429
}

DOI 10.26821/IJSRC.8.6.2020.8601>

\begin{abstract}
$\grave{A} b{ }^{\prime} k u ́$ is a religio-cultural phenomenon that its reality is never in doubt among the indigenous Yoruba people of the south western part of Nigeria.Àbiku is believed to belong to the guild of wicked children who take sadistic pleasure in the sadness of their parents as a result of their repeated death. Various efforts by their parents to retain them often proved abortive in many occasions. However, some of the existing publications on modern health care delivery system in recent time denied its reality with the opinion that the phenomenon of Àbíkú is a ruse, superstitious and figment of spiritual imagination. Their claim is that the resultant death of the infants then was as a result of lack of adequate medical care delivery and that the belief has faded out as a result of modern health care facilities in contemporary Yoruba society. This paper aims at revisiting the phenomenon of Àbíkú among the Yoruba people in the throes of modernity with the attendant orthodox health care delivery system. The study employs primary and secondary methods of data collection and adopts historical and phenomenological approaches to analyse data collected. Findings reveal that Àbíkú is a spiritual phenomenon that goes beyond empirical verification. Its reality is never in doubt as Yoruba people always try every available means to retain any baby suspected or believed to be an Àbíkú. Also, the inability of science to probe into the reality of Àbíkú does not negate its reality in the contemporary Yoruba society. The paper concludes that Àbíkú phenomenon is a reality that could not be explain through empirical analysis of the modern science. It therefore recommends that since the issue of Àbíkú is a spiritual matter, science should admit its limitation and focus on its area of jurisdiction.
\end{abstract}

Keywords: Àbíkú phenomenon, indigenous Yoruba, paradox, health care delivery, Àbíkú reality 


\section{Introduction}

A discussion on the Àbíkú phenomenon in this contemporary Nigerian society might be regarded as a mere wasting of time as the phenomenon is a religio-cultural issue that defies medical and scientific explanations. The world we live today is been rule by science and explanation given to every occurrence is science oriented. Nevertheless, the existence of Àbíkú in the Yoruba worldview is a reality that does not generate any argument. Thus, the paradoxical nature of this study demands for academic research response.

The Yoruba people belong to one of the three major ethic groups in Nigeria. They can be found in the western part of the country. Also, a considerable number of them can be found in the Republic of Benin, Togo, Sierra-Leone, Cuba and Brazil (Ogunleye, 2008). Before the advent of Islam and Christianity in Nigeria, the Yoruba people were predominantly indigenous worshippers. Aceording to Bolaji Idowu, they were 'religious in all things' and their keynote of life is religion (Idowu,1982). Religion permeates the lives of Yoruba so much that it expresses itself in multi-various ways. Among the various ways through which religion manifest in their lives is the belief in the existence of Àbíkú; born-todie child.

Àbíkú is a Yoruba derivative word that describes a child who is born with the aim of dying repeatedly before the age of maturity or at the appreciative stage in life. It is a word that has no direct English word translation but literally translated as born-to-die. Before the Àbíkú child is born, it is predestined to die. Hence, the name 'born to die'. The phenomenon of born-to-die children is not limited to the Yoruba people alone. It is known as Ogbanje among the Igbo people and amanakpa among the Efik/Ibibio; both in the eastern part of 
Volume 8 Issue 6 June 2020

Nigeria (Ilechukwu, 2007). Also, it is known as Nwonnheowa among the Ikwerre people of

Rivers state (Wotogbe-weneka, 2015). Having known this peculiar child in various Nigerian communities, the focus of this study shall be on the Yoruba people. The significance of this study lies in its attempt to establish the fact that the inability of science to probe into the reality of $A b i k u$ does not negate its reality among the Yoruba.

\section{Àbíkú in the Yoruba Worldview}

Àbíkú, among the Yoruba, are children who die repeatedly before they reach the stage of puberty. They are believed to belong to the guild of wicked children who take sadistic pleasure in the sadness of their parents. In the word of Idowu, Àbíkú is a baby that died in immediate successions not long after his or her birth (Idowu, 1982). Other members of the guild include: emere, elere and elegbe. According to Idowu (1982) and Ilechukwu, (2007), members of this guild are companies of wandering spirits. Their mode of operation is by entering into the womb of the unsuspecting pregnant woman who is walking around during the sunny period of the day. In the oral interview conducted with Mrs. Akanni (2020), Àbíkú spirit could enter pregnant women's womb in the market place. Also, showing unnecessary kindness and generosity to free range and unknown children could attract Àbíkú into ones family, hence, the Yoruba popular proverb: oore niwon (kindness has limit). It is believed that Àbíkú children come into the world after they have entered into a covenant with their spiritual peer groups with the aim of returning at a specific time (Adegbola,1983). Coupled with this is their interest in making their parents very sad and rendered them both 'financially and emotionally exhausted' (Burlew, Evans \& Oler, 1989). In order to keep the covenant, the Àbíkú would be working on the returning journey shortly after the birth. Effort would be set in motion to render ineffective all attempts to retain and confined them to the earth. This 
scenario was highlighted by Wole Soyinka, a typical Yoruba man, in his poem dedicated to Àbíkú. The Àbíkú child, in the poem, said inter alia:

\author{
In vain your bangles cast \\ charmed circles at my feet \\ I am Àbíkú, calling for the first \\ And repeated time ( Soyinka,1986:62).
}

From the above quotation, Àbíkú was sure of himself that nothing could stop him from dying. Thus, they were found of mocking their parents by telling them that they were wasting their energy and time by their attempts to tie them down on earth.

Furthermore, one of the Yoruba myths shed light on the reason while Àbíkú is always hell bent on going back (died). Àbíkú is believed to have family in the spiritual world. Unlike deities who often receive regular sacrifices from the people of the world, nobody offers any sacrifices to Àbíkú. In their anger and out of frustration, the Àbíkú decides to come into the physical world. This action therefore gives them the opportunity to have enough food to eat and in the process provide food for their spiritual family (Alabere, 2016). Nevertheless, in spite of the caring for the Àbíkú by their unsuspected earthly parent, they will still die at their appointed time. In most cases this time often fall on the importance occasions of their life and the period of happiness such as during marriage and period of festival when everybody is in festive mood. This was also attested to by Soyinka (1986), when he writes; 'the ripest fruit was saddest.' The Àbíkú prefer this period to another time so that the grief would be great as the cry of their parents and sympathizers excites the Àbíkú spirit world (Alabere, 2016). Also, the tears that come out of the eyes of the bereaved parents and their sympathisers are delicious juice for the Àbíkú and their spiritual family. (Ayeyemi, 1995). 
Another writer, John Pepper Clark, who was not a Yoruba man but was familiar with the terrain of the Yoruba worldview, described Àbíkú as 'spirit children; born only to die young and then return to be born again repeatedly to the same mother' (Clark, 1986). He added that a dead child suspected to be an Àbíkú would be marked with sharp object with the hope that if he comes again, he would be recognised. It is when the Àbíkú children are recognised that their parents would be planning on how to force them to stay and grow like any other child. In his poem, Clark states:

We know the knife scars

Serrating down your back and front

Like beak of the sword-fish

And both your ears notched

As a bondsman to this house

Are all relics of your first comings (Clark 1986:61).

The Àbíkú phenomenon is therefore a religio-cultural issue that was known by the Yoruba and the non-Yoruba people as well. Although the phenomenon goes beyond empirical verification, its reality has never been in doubt.

\section{Measures Towards Retaining Abiku Children}

Based on the strong determination of Àbíkú to die at all cost, their parents often put up some measures to prevent them from dying. First and foremost of these measures is the employment of the services of medicine man known as the Onisegun, herbalist known as Amoju ewe and diviner known as the Babalawo. These are special people that have the working knowledge of the use of plants, animal substance as well as supernatural forces to prevent or cure disease (Olanisebe, 2005). Apart from this, they posses esoteric knowledge 
Volume 8 Issue 6 June 2020

through which they can appeal to the spiritual world and supernatural forces to discover causes and solution to a particular situation. These service men in order to prove their worth, would prepare spiritual iron bangles (sekeseke), sacrifice of various kinds, application of cowry shells, palm oil and other indigenous preparations to retain the Àbíkú. In most cases, all these preparations were often rendered ineffective by Àbíkú. It is this failure on the part of the service men that led to a popular saying among the Yoruba: Àbíkú so oloogun di eke (Àbíkú turns the medicine man to be a liar).

The second measure is the offering of a potent ritual. It is interesting to note that ritual is an essential aspect of Yoruba religion and its importance in their day-to-day life can not be over emphasised. It is a 'performance of a ceremonial acts prescribed by tradition or by sacerdotal decree in a specific observable context demonstrating a mode of behaviour exhibited by all societies' (Ogunleye, 2014). There are various types of ritual but the one we are focussing here is the type that Idowu (1982) called A-ye-pin-un meaning "that which alters an agreement." As said earlier, Ȧbikú belongs to the children of wandering spirits given to the prank of entering into pregnant woman and being born only to die at an appointed time. Sequel to this, whenever any child is suspected to be an Àbíkú, the parents would take every measure to retain him or her by breaking the covenant of death he or she entered into with his or her companions. In most cases, A-ye-pin-un ritual is often prescribed when an oracle is consulted. This ritual is of paramount importance when a confirmed Àbíkú is ill and at the verge of death.

Another way of preventing Àbíkú from dying is by giving appealing names to them by their parents. The reason behind this is to beg and appeal to Àbíkú to cast off their wandering spirit and stay permanently with them. The appealing names were also meant for Àbíkú to consider the suffering of their mothers and stay. Prominent among the names are Durojaye 
Volume 8 Issue 6 June 2020

meaning stay and enjoy life, Durodola meaning stay for honour, Durosomo meaning stay and be a real child, Duroriike meaning stay and enjoy caring, Malomo meaning do not go again, Kokumo meaning he/she do not die again and the host of others. With these names, some Àbíkú would decide to stay on earth with their parents while some would still remain adamant and return.

Moreover, giving of abusive and derogatory names to Abiku. Whenever the above mentioned measures failed to prevent Àbíkú from dying, their parents often employ derogatory and abusive names to address Àbíkú children. One of these names is : Kosoko meaning there is no hoe. That is, if you die now there is no hoe that would be used to dig your grave. Another name is Okoya meaning the hoe for digging your grave has broken. We also have Igbekoyi, the name which indicates that the bush which Abiku parents used to bury them has rejected them. In addition to this name is Aja, that is dog. The major reason behind this type of name is to ridicule $\mathbf{A b i k u}$ children and to show that their parents no longer care much about them. Just like other measures, some Abiku will stay because of these embarrassing names while some would still die (Ogunleye, 2020-Personal experience).

Last but not the least among the measures against Àbíkú is deformation and mutilation of their bodies. With reference to this measure many actions would come to play. When an Àbíkú child is confirmed and all other measures to retain him proved abortive, the elders of the household would step in to mutilate the body of such an Àbíkú child. The mutilation can be cutting of a finger or toe. It can also be cutting of one ear. In a serious case, when the elders were highly aggressive, the back of a hoe is often use to hit the legs of an Àbíkú so as to deform those legs. In addition, hot iron implements, such as knife are also use to make marks on their faces and bodies. The reason behind all these is to disfigure him or her so as to be able to recognise that particular Àbíkú, without any iota of doubt, when he or she returns. 


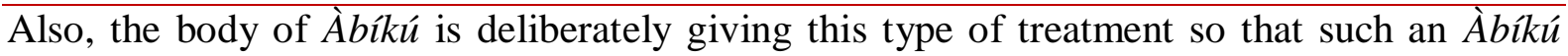
would feel badly treated and therefore lose interest in coming into the family again (Wotogbe-weneka, 2015).

\section{Abiku in the Throes of Orthodox Medication}

Sequel to the emergence of civilization, western education, modern religions and development of science and technology that brought about orthodox medication, the Àbíkú phenomenon has been a controversial issue because it cannot be subjected to scientific verification. Majority of the elites were of the opinion that the so-called Àbíkú were children in those days, who lack adequate medical care and proper hygiene. As a result of this, the phenomenon has been described as a ruse, superstitious and a product of spiritual imagination (Otakpor, 2016).

Various questions were therefore raised in the attempt to press home their claims. Among the major questions is: how do we establish the fact that it is the same child that was born? Another one is, how do we reconcile the biological fact of human reproduction through sexual intercourse with the Àbíkú's entrance into the womb of a pregnant woman? These are part of the various questions of some elites who had been influenced by the western orientation. These challenges and changing phases of African (Yoruba) culture in recent years therefore demand for regular 'research responses' (Adejumo, 2020). In the same vein, Olupona (2012), asserts that the 'ever-changing landscape of African religious culture and society requires that scholars provide regular assessment' of their various fields. It is therefore the opinion of this study that failure to address issues such as the Àbíkú phenomenon would be considered a serious disservice to the cultural development among the Yoruba people in Nigeria. 
With reference to the question on how to establish the fact that it is the same child that is reborn. In Yoruba tradition, when a child is confirmed to be an ardent Àbíkú, his or her body is mutilated for easy recognition at his or her subsequent coming. The empirical verification of this fact has been demonstrated in some children that were born with such marks and cuts showing that the particular child is the one who was born earlier and was marked after death (Akinseye, 1999). A renowned poet, J. P. Clark (1986), also attests to this when he says: 'We known the knife scares serrating down your back and front... are relics of your first coming.' On whether the marks and cuts are accidental or coincidental, what is certain is that those marks are peculiar ones as they were put in notable parts of the body, such as: face, cheek, lips, forehead, toes and fingers.

Coupled with this mode of identification is the time and timing of the death of Àbíkú. Unlike any other child, Àbíkú dies at a fixed date that will bring sadness to their parents. They could suddenly change their good health condition to failing one which would eventually lead to death (Ikechukwu, 2007). This period, in most cases, is a period when happiness is at the peak in family. For instance, such period could be time of naming, puberty, marriage and during an important festival. The choice of this period is based on the excitement that sadness and weeping of Àbíkú 's mother brings to the Àbíkú's spiritual world.

Another means of identifying an Àbíkú child is through divination. This is the practice that reveals the hidden causes of illness and other forms of affliction that may not be known ordinarily (Mutombo, 2009). It is a reliable source of knowledge and information on the identity of Àbíkú. When any child is suspected to be an Àbíkú among the Yoruba, the parents of such a child would consult Ifa; a prominent divination system among them, through a diviner known as Babalawo (Ifa Priest). It is the responsibility of the Babalawo to determine the sacrifice that will go along with the pronouncement of the divination (Ogunleye, 2019). 
On the second issue; how to reconcile the biological fact of human reproduction through sexual intercourse with the Àbíkú 's entrance into the womb of a pregnant woman? To address this issue, we need to understand the Yoruba world view. For instance, Yoruba as a typical African operates a culture that accommodates the combination of physical with the spiritual world; which lack of in-depth understanding makes it difficult for the science to penetrate (Neba, 2011). There is no clear cut demarcation between the physical and the spiritual world of the Yoruba people. This is because what happens in physical realm is a manifestation of what had been concluded in the spiritual realm. The reality of spirit and mystical powers is not a matter of argument among the people. It is an 'axiom and potent factor' in their daily religious life (Adogbo, 2000).

As a result of this, we cannot rule out the possibility of Àbíkú spirit getting into the womb of a victim to be born persistently under the assumption that we cannot explain it as biological as in the case of conception. From the Yoruba point of view, it is not everything that can be subjected to scientific verification. This was also attested to by Oluwole Sophie as cited by Akinseye (1999), that; ' nothing in our experience tells us that the real is only the scientifically provable. The claim that Àbíkú are children suffering from sickle cell anaemia had been negated by the research carried out by Whitten \& Fischhoff (1974). The research was an attempt to linking Àbíkú with the children suffering from sickle cell disease. It is amazing to note that none of the patients believed to be Àbíkú at the site of investigation had sickle cell disease.

\section{Conclusion}

This study revisited the phenomenon of Àbíkú among the Yoruba people in Nigeria. The phenomenon is an age long issue showing the belief of Yoruba in the spiritual world of Àbíkú. Before the emergence of Orthodox medicine and medical personnel that accompanied 
Volume 8 Issue 6 June 2020

colonial masters and early missionaries. The reality of Àbíkú has never been in doubt. Whenever a suspected $\grave{A} b i k$ ú is confirmed, the parents of such a child would be seeking for every measure to secure his/her stay. Among the measures are: oracular consultation, employment of the services of medicine men, herbalist and diviners. Others include: giving of appealing and derogatory names, ritual observation and mutilation of Àbíkú 's bodies.

However, with the arrival of Orthodox medicine and development in science and technology, the Yoruba belief in Àbíkú has been described as a ruse and superstitious. This claim was informed by the failure of science to explain the phenomenon and the influence of western orientation on the educated Yoruba elites. They therefore concluded that the so called Àbíkú were children suffering from sickle cell anaemia disease; who do not have adequate health care treatment.

Nevertheless, from the Yoruba perspective, Ábíkú phenomenon is a reality that does not generate argument; more so as research had proved that it is not everything that science cannot prove that is false. Various phenomenological researches, personal experience on Àbíkú and physical characteristics of Àbíkú have proved the reality of Àbíkú beyond any reasonable doubt. In addition, attempt to link children suffering from sickle cell disease with Àbíkú has proved negative.

In conclusion, the paper is of the opinion that Àbíkú phenomenon is a reality which could not be explained through empirical analysis of the modern science. It therefore recommends that since the issue of Àbíkú is a spiritual matter, science should admit its limitation and focus on its area of jurisdiction. 


\section{References}

Adegbola, E .A. A. (1983). Traditional Religion in West Africa. Ibadan,Nigeria: Onibonoje Press.

Adejumo, P. O. (2020). 'Research Without Tears: Building the Competencies of the $21^{\text {st }}$ Century Nursing Students in Research and Scholarly Endearvour.' A Conference presentation during A Week-long online Research Conference Organized by the Nigerian University Nursing Students Association, on 11 May, 2020.

Adogbo, Micheal. P. (2000). 'The Spirit World of African Peoples'. In Erivwo, S. U \& Adogbo, M. P. (eds) Contemporary Essays in the Study of Religions. Lagos, Nigeria: Fairs 7 Exhibition Nigeria Ltd.

Akanni, Deborah. (2020). An oral interview with Mrs. Akanni Deborah, aged 83 years, at her residence, Agbaluku- Arigidi Akoko, Ondo state, Nigeria.

Akinseye Francis. (1999). 'Introduction to Philosophy of Religions' In OgunsakingFaberebo, S.1. (ed). Religious Preriscope. Kol.1. Ondo, Nigeria: Adeyemi College of Education.

Alabere, Regina. (2016). 'A Review of “Abiku” by Wole Soyinka.' Wikipedia. Org. Accessed on 15 April, 2020.

Ayeyemi, Ofoloro. (1995). An oral interview with late Mrs. Ayeyemi Ofoloro, aged 85years, at her residence, bk. 16B, Ido street, Ile- Ife, Osun state, Nigeria.

Burlew, A. K., Evans, R. \& Oler, C. (1989). 'The Impact of a Child with Sickle Cell Disease on Family dynamics.' Annals of New York Academy of Sciences, 565, 161-171.

Clark , John Pepper. (1986). 'Abiku.' In Nwoga Donatus (ed). West African Verse: An Anthology . United Kingdom : Longman Group Limited .

Idowu, Bolaji. (1982). Olodumare : God in Yoruba Belief. Ikeja, Nigeria: Long man Nigeria Limited.

Ilechukwu, Sunday T. (2007). 'Ogbanje / Abiku and cultural conceptualizations of Psychopathology in Nigeria.' Mental Health, Religion and Culture. 10 (3); 246. DOI: https://doi.org/ 10.1080/13694670600621795

Mutombo Nkulu- N'sengha. (2009). Divination System. In Asante, M. K \& Mazama, A. (eds). Encyclopedia of Africa Religion. California: Sage Publications.

Neba, Ndenecho E. (2011). 'Traditional Health Care System and Challenges in Developing Ethno pharmacology in Africa: Example of Oku, Cameroon.' In Studies on 
Ethno-medicine.5(2),133.DOI:

https://doi.org/10.1080/09735070.2011.11886400

Oghenero, Ezaza. (2015). 'Analysis of the Poem “Abiku” by Wole Soyinka.' Available at https://m.facebook.com. Accessed on 15 March, 2020.

Ogunleye A. Richard. (2019). 'Ifa: An Epistle to the Indigenous Yoruba Worshippers in Nigeria'. In Journal of African Interdisciplinary Studies.' 3 (1). 68.

Ogunleye, A Richard. (2014). 'Ritual Efficacy in Traditional African Environment'. In Journal of Pan African Studies. 6 (10). 209.

Olanisebe, Samson. O. (2005). 'Western and Traditional Herbal Medicines in Nigeria: The Biblical Perspective' in Religions: A Journal of the Nigerian Association for the Study of Religions. 15 \& 16. 54.

Olupona, J. K. (2012). 'Forward.' In Bongmba, E.K. ed. The Wiley-Blackwell Companion to African Religions. UK: Blackwell Publication Limited

Oluwole, Sophie (1978). 'On Existence of Witches.' Second Order. (1\&2). In OgunsakingFaberebo, S.1. (ed). Religious Preriscope. Kol.1. Ondo, Nigeria: Adeyemi College of Education.

Otakpor, Nkeonye. (2016). Superstition: Aphilosophical Analysis. Benin City, Nigeria; Mindex Publishing Co. Ltd.

Soyinka, Wole. (1986). 'Abiku.' In Nwoga Donatus (ed). West African Verse: An Anthology. United Kingdom : Longman Group Limited .

Whiten, C. F, and Fischhoff, J. (1974). Psychosocial Effects of Sickle Cell Disease. Archives of Internal Medicine, 133, 681-689.

Wotogbe-Weneka,Wellington. (2015). 'Burial Rites and Reincarnation in the Indigenous Tradition of the Ikwerre People of Upper Niger Delta.' In Ogungbile, David O. (ed). African Indigenous Religious Traditions in Local and Global Contexts: Perspectives on Nigeria. Lagos: Malthouse Press Limited. 